IZA DP No. 7195

Investment under Company-Level Pacts

Lutz Bellmann

Hans-Dieter Gerner

Olaf Hübler

January 2013

Forschungsinstitut zur Zukunft der Arbeit Institute for the Study of Labor 


\title{
Investment under Company-Level Pacts
}

\author{
Lutz Bellmann \\ University of Erlangen-Nuremberg, \\ $I A B$ and IZA \\ Hans-Dieter Gerner \\ Institute for Employment Research (IAB)
}

Olaf Hübler

Leibniz University of Hannover, $I A B$ and IZA

\section{Discussion Paper No. 7195 \\ January 2013}

IZA

\author{
P.O. Box 7240 \\ 53072 Bonn \\ Germany
}

\author{
Phone: +49-228-3894-0 \\ Fax: +49-228-3894-180 \\ E-mail: iza@iza.org
}

\begin{abstract}
Any opinions expressed here are those of the author(s) and not those of IZA. Research published in this series may include views on policy, but the institute itself takes no institutional policy positions. The IZA research network is committed to the IZA Guiding Principles of Research Integrity.

The Institute for the Study of Labor (IZA) in Bonn is a local and virtual international research center and a place of communication between science, politics and business. IZA is an independent nonprofit organization supported by Deutsche Post Foundation. The center is associated with the University of Bonn and offers a stimulating research environment through its international network, workshops and conferences, data service, project support, research visits and doctoral program. IZA engages in (i) original and internationally competitive research in all fields of labor economics, (ii) development of policy concepts, and (iii) dissemination of research results and concepts to the interested public.
\end{abstract}

IZA Discussion Papers often represent preliminary work and are circulated to encourage discussion. Citation of such a paper should account for its provisional character. A revised version may be available directly from the author. 


\section{ABSTRACT}

\section{Investment under Company-Level Pacts ${ }^{*}$}

To improve their competitiveness the companies aim to increase the funds available to finance the necessary investments. In order to reduce wage costs company-specific deviations from industry-level wage contracts are concluded. Company-level pacts between the management and the works council are often preferred in comparison to agreements between employers' association and unions because the former negotiating partners are better informed about the economic situation of a company and have less goal conflicts than the latter. Moreover, these company-level pacts might reduce the "hold-up" problems which arise once specialized investment is made. Therefore, this paper investigates whether such agreements affect firm-level investment. Based on the IAB Establishment Panel Survey 2001-2010 our estimates reveal that the adoption of a company-level pact leads to a higher investment rate than in other firms driven by re-investment. However, the Great Recession has damped this positive influence. From our econometric analysis we cannot detect any increase in investment during the negotiation phase. After the expiration of a CLP, lower reinvestment and a small increase in net investment take place. Furthermore, our econometric results show that the company-level pacts' success depends on the specific measures which are agreed and on the duration of the pacts.

\section{JEL Classification: J50, J52, J53, D24}

Keywords: industrial relations, pacts for employment and competitiveness, investments

Corresponding author:

Olaf Hübler

Institute for Empirical Economics

Faculty of Economics and Management

Leibniz University of Hannover

Königsworther Platz 1

30167 Hannover

Germany

E-mail: huebler@ewifo.uni-hannover.de

\footnotetext{
${ }^{*}$ We are grateful to Bernd Fitzenberger, Knut Gerlach, Robert A. Hart, Claus Schnabel and Gesine Stephan for their comments.
} 
"It is widely acknowledged that German reforms of the past decade have been designed with competitiveness and employment in mind; thereby the low wage increases have had a material effect on export competitiveness in a range of manufacturing industries, such as industrial machinery" (Spence/Hlatshwayo 2011).

\section{Introduction}

A declining demand for companies' products and services decreases their profits and therefore, also their investment activity, a phenomenon which can occur not only during the Great Recession. To improve their situations, companies seek to reduce their costs and try to increase the funds available to finance the investments necessary to avoid a downturn in their competitiveness. Wage costs can be reduced by company-specific deviations from an industry-level wage contract. In fact, in recent years we have observed a tendency towards increased local bargaining and flexibility through the negotiation of opening clauses and company-level pacts for employment and competitiveness (CLPs) in Germany. Especially within the context of CLPS, works councils agree to company-specific deviations from an industry-level contract by accepting reduced wages or prolonged working time in exchange for employment guarantees or investment programs. Moreover, these contracts are associated with the safeguarding of firm locations in accordance with a firm's global sourcing and production strategies. Recent trends in collective bargaining and worker representation in Germany, which can be observed since the 1990s, show a decline in both sectoral agreements and works council coverage (see e.g. Hassel, 1999, Hassel/Rehder 2001, Addison et al. 2010, 2012, Ellguth/Kohaut 2012).

"Clearly, PECs - company-level pacts - are adding to the pressure for the decentralisation of collective bargaining observed in western Europe since 1980. Sometimes they have benefited from the decline of sector-level negotiation (as in the UK), and sometimes they have been made possible by the widening of the field of responsibility bestowed upon company negotiation (as in France, Italy and the Netherlands). In other countries, they reflect the introduction of 'opening clauses' or 'hardship clauses' into sector agreements (as in Austria and Germany)" (Sisson 2001). In the United States and Canada, similar agreements have been negotiated through concession bargaining, which was widespread in the $1980 \mathrm{~s}$ (see e.g. Bell 1995, Cappelli 1985, Eaton/Verma 2006). 
In terms of agreements between employers and employees, agreements between management and the works council are often preferred in contrast to agreements between employers' associations and unions because the former negotiating partners are better informed than the latter about the economic situation of a company and are less prone to having conflicting goals for the outcome of a negotiation.

However, these pacts encounter a structural problem as employee concessions are made before employers are able to redeem the pledges that they have made to employees (e.g. Bogedan et al. 2011). In addition, the medium- and long-term effects of CLPs on competitiveness are not under the control of employers because competitiveness strongly depends on the sector and a companies' market position (cf. e.g. Sisson/Martin Artiles 2000). Furthermore, unions could seek to expropriate quasi-rents, which arise once specialised investments are made. CLPs might reduce this "hold-up" problem because short-term considerations can be overcome by these contracts. This argument is valid irrespective of the stage of the business cycle at the time a CLP is made.

The focus of previous empirical investigations on CLPs was on the impact of such agreements on employment, training and the economic positions of firms. Until now, however, detailed investigations on the effects of CLPs on investment have been absent. Such a study is of particular importance because if establishments refrain from investment, this omission may have a negative impact on the long-term growth potential of an economy.

This article seeks to fill the research gap and applies econometric methods to study firm investment decisions at the level of individual plants. Using the IAB Establishment Panel Survey, we are able to investigate heterogeneity in the behaviour between different types of plants. Structural information about the establishments, beginning with information on the establishments before the CLPs were finalised, is necessary to evaluate the impact of CLPS. These data are provided by the IAB Establishment Panel Survey.

Our intention is to analyse the investment activities of establishments with CLPs in comparison to the investment activities of establishments without these pacts. Are there differences between the replacement investments and the net investments of these two groups of establishments? Are specific provisions in CLP agreements more successful in promoting investment than other CLP provisions? Is the contract duration important to subsequent investment activities? Are there higher fundamental reductions in investment 
activities during the great international crisis of 2008 and 2009 compared to the pre-crisis period?

The paper is structured as follows: Section 2 gives a short overview of the related empirical literature. Section 3 describes the IAB Establishment Panel Survey data and discusses methodological issues. Section 4 presents descriptive findings. Section 5 contains our econometric results. Section 6 concludes the paper.

\section{Literature related to company investments and company-level pacts}

\subsection{Business investment}

Traditional investment functions are generally modelled with respect to classical and accelerator theories. Profit levels and changes in demand levels are the major determinants of these calculations, and the estimates of these relations are based on aggregated data. However, during the last twenty years, economists focus has shifted to the analysis of investment at the firm level. Studies on firm-level investment are based on the standard accelerator-profit specification. A good example of such a study is Mairesse et al. (1999). Their results demonstrate that, especially in France, profits do not affect investment in the long-run, and profits only slightly affected investments during the period from 1985 to 1993, in contrast to the period from 1971 to 1979.

Investments also depend on financial limitations and expectations. Eisner (1978) emphasises that business investments are ideally selected based on anticipation of future developments. However, we cannot expect a stable or reliable relationship between investments, on the one hand, and past and current determinants, on the other hand. Fazzari et al. (1988), Mulkay et al. (2000) and Asano (2008) consider the effects of financial constraints on capital investment and develop a model with Tobin's $q$ and a cash-flow variable. The influence of the latter on investment is more important, and the latter is more stable over time than the former. Bond et al. (2005) also test the importance of cash flow on investment. Using firmlevel data for the period from 1985 to 1994, they find that the cash flow of German firms in contrast to the cash flow of British firms is not informative to econometric models of investment. 
Fuss and Vermeulen (2004) find that demand uncertainty depresses planned and realised investment, while price uncertainty is insignificant. This finding is consistent with the behaviour of monopolistic firms with irreversible capital. Furthermore, firms revise their investment plans very little and may do so in response to new information on sales growth, but not as a result of reduced uncertainty.

Caggese (2007) considers a dynamic multifactor model of investment with financing imperfections, adjustment costs, and with fixed and variable capital. He tests the influence of financing constraints based on a reduced-form variable capital equation. Simulation results show that this test correctly identifies financially constrained firms even when the estimation of the firms' investment opportunities is very noisy. Empirical investigations confirm the validity of this test using a sample of small Italian manufacturing companies.

The investment sensitivity of debt under uncertainty is discussed and empirically investigated by Baum et al. (2010). Their estimates show that the influence of leverage on capital investment may be stimulating or mitigating, depending on the effects of uncertainty. They employ an unbalanced panel of 7,769 firm-years, covering manufacturing firms during the period from 1988 to 2005. The panel data are drawn from the Standard and Poor's Industrial Annual COMPUSTAT database. They find that firm-specific and CAPM-based measures on investment have a significantly negative effect, while market-based uncertainty has a positive impact.

The impact of the union representation of employees on firm investment is considered in several studies. From a theoretical point of view, unions may exert a negative as well as a positive impact on firm investment. In a traditional model, unions exogenously set wages and may or may not propel firms to substitute capital for expensive labour (Addison et al. 2007). Thereby, the degree of substitutability between capital and labour, as well as the effect of union representation on output prices, determines the ultimate effect on investment. If unions seek to expropriate quasi-rents, which arise once investment in specialised plant equipment has been made, the firms are confronted with a "hold-up" problem. Therefore, a strong presumption in the literature on this topic is that greater worker representation will depress investments in capital, because firms anticipate the "hold-up" problem. E.g. Bronars and Deere (1993) estimate a negative effect of unionisation on investment, but the empirical significance of hold-up effects in the labour market is unclear. Existing studies suggest that wages respond to employer-specific gains in productivity (e.g. Gürtzgen 2010). Card et al. (2011) argue that hold-up depends on whether the wage bargaining process allows the firm 
to recoup its investment costs before splitting the rents with employees, and not on rentsharing per se.

Freeman and Lazear (1995) argue that a works council acts as a communicator between management and workers, and thus the likelihood of a "hold-up" problem might be reduced. This argument is especially true if the management and the works council successfully negotiate a CLP. Thereby, the firms' investment incentives are increased. In contrast, an economic crisis tends to decrease the investment incentives because it deteriorates business expectations. In addition, strategies to cut wage costs can be regarded as a prerequisite for enhancing the firm's ability to finance investment projects. Empirical studies on the effect of works councils do not provide a clear picture. The impact on innovation and investment is ambiguous. Addison et al. (2001), Addison et al. (2007) and Jirjahn (1998) cannot find proof of significant effects of the existence of a works council on process and product innovation. If the works council is not modelled as an exogenous variable but is instead instrumented as the probability of product but not of process innovation, then product innovation is significantly higher in establishments with councils (Addison et al. 1996). In middle-sized firms with 100-300 employees, the effects of the works council on investment in Old and New Economy are significantly positive in Germany, where the indirect effect via reorganisation and training of the workforce are dominant compared to direct effects (Hübler 2003). Investment in the environmental protection in establishments is also positively correlated with the existence of a council, if the council is led by employees rather than firm managers (Askildsen et al. 2006).

\subsection{Company-level pacts}

Company-level pacts (CLPs) are specific to Germany. The major difference of CLPs to the concession bargaining in North America is that the contracts are bilateral, meaning that not only employees abandon privileges. The employers also promise measures to improve the competitiveness of the firm and to stabilise employment. Furthermore, concession bargaining is only focused on establishments that have evident economic problems.

Usually, management alone decides whether and how much shall be invested by a firm. However, under a CLP, the works council and employees are directly or indirectly involved in the decision making process. Some pacts agree explicitly on investments for a specific location, while others are silent on this issue. Other pacts include agreements on the modernisation of a firm's capital stock. CLPs may provide a solution to the "hold-up"- 
problem. Unions are not able to expropriate quasi-rents, which arise from firm-specific investment if wages are set simultaneously (or in conjunction) with investment. In the standard setting, under-investment arises because of the possibility of wage re-negotiations by unions after the installation of sunk capital by firms. However, with CLPs, a binding agreement on wage moderation and other deviations from collective bargaining is signed before the installation of new capital.

The main intentions of CLPs are to ensure employment stability and to improve firm competitiveness. Employees abandon some monetary and non-monetary privileges, while the employer accepts measures to stabilise firm employment. In other words, CLPs follow the principle of "do ut des". This principle is more than a gift exchange in the sense of Akerlof (1982) because a CLP agreement is explicit, not implicit. The literature focuses on the employment effect of CLPs (Sisson/Martin Artiles 2000), while the impact on investment is hardly considered. An exception is provided by Lesch (2008). Using data for the German mechanical engineering and electrical machinery sector in the year 2007, he finds that employers' pledges are mainly in the field of employment $(75,2 \%)$, location guarantees $(52,8 \%)$, arrangements for financial participation of employees $(35,4 \%)$ and investment guarantees (33,8\%). Despite the widespread incidence of CLPs in some economic sectors, the number of companies adopting CLPs is rather limited. Company case studies are presented by Zagelmeyer (2010), and a discussion of the problems and features of CLPS can be found in Massa-Wirth/Seifert (2005) and Seifert/Massa-Wirth (2005). A survey of works councils, conducted by the WSI, explains economic and institutional factors that influence the spread and composition of these concessionary agreements. Using data from the IAB Establishment Panel Survey 2004-2006, Ellguth and Kohaut (2008) investigate the probability that a CLP negotiation will be successful. Econometric studies reveal mixed impacts on employment (Hübler 2005, Bellmann et al. 2008, Bellmann/Gerner 2012b), on firm investment in further training (Bellmann/Gerner 2012a) and on enterprises' economic situations (Hübler 2006).

Estimations based on the WSI data (Hübler 2005, 2006) demonstrate that the agreements are more successful if employers or the management suggest an alliance CLP rather than if the works councils or unions suggest a CLP. Apart from very short-run positive effects, the influence of CLPs on employment is negative. In the long-run, however, this trend has turned around, and in-plant alliances have been found to be successful. Sometimes, renegotiations can help to improve the situation. Among CLP firms, during good economic times, an increase in the working hours of skilled workers without an adjustment of wages improves the order situation of a firm. Symmetrically, short-time work and a reduction of regular 
working hours can be successful under poor economic conditions. These sequences of events during the durations of alliances entail two important effects. First, negative long-run effects on profits follow very short-run positive effects. Second, the effects on profits can be separated between competitiveness and crisis CLPs with obvious advantages of the former type of CLP. As time passes, the differences between these CLPs do not vanish completely, but they are less pronounced.

Bellmann et al. (2008) base their empirical investigation on the IAB Establishment Panel Survey of the period from 2004 to 2007. They also analysed the effects of CLPs on employment. Difference-in-differences estimators show insignificant effects of CLPs on employment. The development of employment does not differ between firms with and without CLPs. The study does not find evidence that CLPs help to stabilise or increase employment. This finding holds even if the endogeneity of pacts is taken into account. Bellmann and Gerner (2012b) find evidence that the adoption of CLPs is connected with smaller employment losses during the Great Recession.

The hypothesis that CLP establishments provide continuous training more often is tested by Bellmann and Gerner (2012a). Their study is based on the IAB Establishment Panel data from 2003 to 2007. Cross-section time-series regression and difference-in-differences models, combined with matching, are applied. The treatment effect is measured by the coefficient of the interaction term in a nonlinear difference-in-differences model. The regression coefficients for the CLP variable are significantly positive. The adoption of difference-in-differences matching techniques does not corroborate this hypothesis of a significant impact of CLPs on continuous employer-provided training but reveals the importance of a selectivity effect.This rather pessimistic assessment of the extent of continuous training undertaken by establishments pursuant to CLPs means that training is not enhanced in exchange for moderate wage hikes or employee working time concessions.

To summarise our short survey on the related literature concerning company investment and CLPs and studies conducted with data at the establishment level, which consider the effect of employee representation on the firm investment incentives: The effects of employee representation on firm investment incentives are ambiguous. CLPs seem to be of special interest because it can be expected that CLPs reduce the "hold-up" problem, which decreases firm investment incentives, despite empirical evidence concerning these agreements. CLP effects on firm employment, firm training and the economic situation of a firm are rather limited and not always positive. This observation holds even when controlling for the different types, phases and durations of CLPS. 


\section{Data and methods}

\subsection{Data}

The German IAB Establishment Panel Survey of the Institute for Employment Research of the Federal Employment Agency (IAB) is a representative survey of German establishments employing one or more employees from the private sector without agriculture, forestry and fishing covered by social insurance (Fischer et al. 2009). The panel started in 1993 with an annual survey of West German establishments and was extended to East Germany in 1996. Since 1996, more than 15,000 establishments have been included in the survey. The IAB Establishment Panel provides information on many labour market topics, including employment, wages, sales, bargaining levels, works councils, profit sharing and investments. Wave 2006 provides many details regarding CLPs including retrospective data. In following waves, it is also asked whether an establishment has a CLP, and, if so, when the pact was adopted. Furthermore, the duration of a pact is identified. We also know whether any negotiations on such arrangements currently persist, whether an agreement existed in the past and is now discontinued, and whether efforts to achieve such an agreement failed in the past. Moreover, we know the reasons for implementing an agreement. A distinction is made between pacts that are designed to improve competitiveness and those that are intended to react to a current crisis.

Our investigation is focused on data for the period from 2001 to 2009. Public sector establishments are excluded. The establishment-level capital stock is approximated by applying the modified perpetual inventory approach proposed by Mueller (2008) that combines firm's i information from the IAB Establishment Panel with those of industry s from the German Federal Statistical Office, where firm i belongs to s:

(1) $\mathrm{K}_{\mathrm{it}}=\mathrm{K}_{\mathrm{i}, \mathrm{t}-\mathrm{1}}+\Delta \mathrm{K}_{\mathrm{it}}$

and

(2) $\Delta \mathrm{K}_{\mathrm{it}}=\mathrm{IR}_{\mathrm{it}}-\mathrm{D}_{\mathrm{it}}+\mathrm{IN} \mathrm{N}_{\mathrm{it}}$,

where $K_{i t}$ is the capital stock, $I R_{i t}$ is the replacement investments, $I N_{i t}$ is the net investment, and $D_{i t}$ is the depreciations of firm $i$ in year $t$. The depreciations are not available from the IAB Establishment Panel. Therefore, they are approximated by 
(3) $D_{i t}=K_{i, t-1} \cdot D R_{s t}$,

where DR is determined by the depreciation rate of industry s

(4) $\mathrm{DR}_{\mathrm{st}}=\left[\left(\mathrm{K}_{\mathrm{st} \text {, structures }} / \mathrm{L}_{\text {st, structures }}\right)+\left(\mathrm{K}_{\mathrm{st}, \text { equipment }} / \mathrm{L}_{\text {st,equipment }}\right)\right] / \mathrm{K}_{\mathrm{st}}$.

The industry values are available from the German Federal Statistical Office - cf. Fachserie 18, Reihe 1.4 -, where L, the life duration, is separately calculated for buildings and structures, on the one hand, and equipment capital of every industry, on the other hand. The starting value of firm's i capital $K_{i 1}$ is approximated by the sum of total investments in the two first years information is available for firm $i$.

\subsection{The model and methods}

The starting point of our firm-level investment analysis is the approach of Mairesse et al. (1999). They develop an accelerator model of investment with error correction. The long-run capital stock is proportional to output:

(5) $\mathrm{k}_{\mathrm{it}}=\theta \mathrm{s}_{\mathrm{it}}+\mathrm{h}_{\mathrm{it}}$,

where $k_{i t}$ is the log of the capital stock in firm i for year t. Analogously, $s_{i t}$ is the log of the output or sales in firm i for year t. Finally, $h_{\text {it }}$ denotes the logarithm of the user costs of capital which are modelled as the disturbance term. A simple dynamic adjustment mechanism takes the form:

(6) $k_{i t}=\alpha+y_{1} k_{i, t-1}+y_{2} k_{i, t-2}+\beta_{0} s_{i t}+\beta_{1} s_{i, t-1}+\beta_{2} s_{i, t-2}+u_{i t}^{*}$,

where $u^{*}$ it is the disturbance term. An autoregressive-distributed lag of length two $(\operatorname{ADL}(2,2))$ is assumed. The next step is the modelling of an error-correction approach:

(7) $\Delta \mathrm{k}_{\mathrm{it}}=\Delta \alpha+\left(\mathrm{\gamma}_{1}-1\right) \Delta \mathrm{k}_{\mathrm{i}, \mathrm{t}-1}+\beta_{0} \Delta \mathrm{s}_{\mathrm{it}}+\left(\beta_{0}+\beta_{1}\right) \Delta \mathrm{s}_{\mathrm{i}, \mathrm{t}-1}+\left(\mathrm{\gamma}_{1}+\mathrm{\gamma}_{2}-1\right)\left(\mathrm{k}_{\mathrm{i}, \mathrm{t}-2}-\mathrm{s}_{\mathrm{i}, \mathrm{t}-2}\right)$

$$
+\left(\beta_{0}+\beta_{1}+\beta_{2}+\gamma_{1}+\gamma_{2}-1\right) s_{i, t-2}+\Delta u^{*} \text { it }
$$

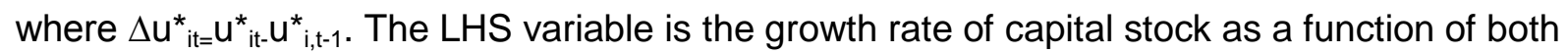
growth rates and levels of information. The error correction term is the difference between 
the log of the capital and that of the sales in year t-2. The long-term effect is measured by the coefficient of $\mathrm{k}_{\mathrm{i},-2-2}-\mathrm{S}_{\mathrm{i},-2}$ and the short-term effect by that of $\Delta \mathrm{k}_{\mathrm{i}, \mathrm{t}-\mathrm{1}}$. The investment ratio $\left(\mathrm{l}_{\mathrm{i} t} / \mathrm{K}_{\mathrm{i}, \mathrm{t}-\mathrm{1}}\right)$ is used as a proxy for the net growth rate of the capital stock $\Delta \mathrm{k}_{\mathrm{it}}$, where $\mathrm{l}_{\mathrm{it}}$ is the investment in firm i for year $t$ and $\mathrm{K}_{\mathrm{i}, \mathrm{t}-1}$ is the capital stock at the end of year $\mathrm{t}-1$. This proxy is described by

(8) $\Delta \mathrm{K}_{\mathrm{it}}=\log \left(\mathrm{K}_{\mathrm{it}} / \mathrm{K}_{\mathrm{i}, \mathrm{t}-1}\right)=\log \left(1+\left(\Delta \mathrm{K}_{\mathrm{it}} / \mathrm{K}_{\mathrm{i}, \mathrm{t}-\mathrm{1}}\right)\right) \approx \mathrm{I}_{\mathrm{it}} / \mathrm{K}_{\mathrm{i}, \mathrm{t}-1}$.

Then the basic estimation equation is

(9) $\Delta \mathrm{k}_{\mathrm{it}}=\delta_{0}+\delta_{1} \Delta \mathrm{k}_{\mathrm{i}, \mathrm{t}-1}+\delta_{2} \Delta \mathrm{s}_{\mathrm{it}}+\delta_{3} \Delta \mathrm{s}_{\mathrm{i}, \mathrm{t}-1}+\delta_{4}\left(\mathrm{k}_{\mathrm{i}, \mathrm{t}-2}-\mathrm{s}_{\mathrm{i}, \mathrm{t}-2}\right)+\delta_{5} \mathrm{~s}_{\mathrm{i}, \mathrm{t}-2}+\mathrm{u}_{\mathrm{it}}$

We start with pooled estimates. The analysis is supplemented by panel methods which consider unobserved heterogeneity and by Tobit estimates, as some firms do not invest in capital every year.

Our main objective is to investigate whether CLPs foster or hinder investment activities. Hence, it is assumed that in the investment ratio equation (9) the absolute term $\delta_{0}$ is not fixed, but is rather a function of the dummy variable CLP. Furthermore, we extend this function by investment determinants, namely by sector dummies (SEC) and firm specific characteristics. We control whether the firm follows an industry-wide central bargaining system (CB), has a works council (WOCO) and has adopted profit sharing (PS) so that

$$
\delta_{0 i t}=\delta_{00}+\delta_{01} \mathrm{CLP}_{\mathrm{it}}+\delta_{02} \mathrm{CB}_{\mathrm{it}}+\delta_{03} \mathrm{WOCO}_{\mathrm{it}}+\delta_{04} \mathrm{PS}_{\mathrm{it}}+\mathrm{SEC}_{\mathrm{it}}{ }^{\prime} \delta
$$

These determinants are more or less time-invariant. If they are neglected, then their influences are essentially components of unobserved firm fixed effects, although not completely as changes are possible after some periods. Due to theoretical arguments and empirical results - cf. section 1 and 2.1 - we expect $\delta_{02}<0$ and $\delta_{03}>0$. In firms with profit sharing, employees tend to hinder firm investment because the level of profits, which can be shared with workers, is lower if investment activities are high. Investment costs reduce profits in the short-run. Kruse (1993, p. 49) expects the same effect from the viewpoint of employers. He argues: "If employees collectively receive a predetermined fixed share of profits, they will naturally share in any increase in profits from new capital investments, thereby decreasing the return on profits for the firm's owners. This decreased return would decrease the incentives for investment ..." Therefore, $\delta_{04}$ should be negative. 
Estimates that are based on the combination of (9) and (10) may contain a selection bias thus that $\delta_{01}$ does not represent the causal effect of CLP on investment. It is possible that investment is determined during the contract period of a CLP by factors other than the existence of a CLP. For example, cyclical effects might be responsible. If cyclical variables are not explicitly incorporated, this influence is added to $\delta_{01}$. Furthermore, investments between CLP and NOCLP firms (CLP=1 and CLP=0) may differ before CLPS are adopted. Some firms have low investment rates compared with other firms in the same industry, which might drive a low investment level firm to negotiate a CLP. To exclude these biases, difference-in-differences estimators (DiD) are determined by

$$
\Delta \mathrm{k}_{\mathrm{iT}}=\mathrm{b}_{0}+\mathrm{b}_{1} \mathrm{D}_{\mathrm{i}}+\mathrm{b}_{2} \mathrm{D}_{\mathrm{T}}+\mathrm{b}_{3} \mathrm{D}_{\mathrm{iT}}+\varepsilon_{\mathrm{iT}} \quad \mathrm{i}=1, \ldots, \mathrm{N} ; \mathrm{T}=0,1
$$

analogously to Meyer's (1995) notation, where $D_{i}=1$ if firm i has a company-level pact, $D_{i}=0$ otherwise; $D_{T}=1$ if period 1 is considered, $D_{T}=0$ otherwise. $D_{\text {iT }}=1$ if $D_{i}=1$ and $D_{T}=1, D_{i T}=0$ otherwise and $\varepsilon_{\mathrm{i \tau}}$ is a zero-mean constant-variance error term. The coefficient of the interaction variable $D_{\text {iт }}$ measures the causal effect of a CLP on the investment rate, given the identifying assumption that the development of the outcome variable would have been the same in CLP and non CLP establishments.

Several robustness checks are conducted. We estimate alternative specifications and analyse the effects directly after the adoption of a CLP and directly after the expiration of a CLP. The investment effects of CLPs are not only compared with those of non CLP firms, but also with those of firms that are currently negotiating a CLP. The intention of such a comparison is to determine whether investment effects can be observed during the CLP bargaining period. The comparison with firms that failed to install a CLP involves a similar objective. Finally, we compare CLP firms with firms that had CLPs in the past but that have expired.

\section{Descriptive statistics}

Recent studies have shown that firms with CLPs are not as successful as expected relative to the goals of these pacts, e.g. ensuring the stabilisation of employment. However, these results are only based on short-term analyses. Longer perspectives can provide a better understanding of CLPs and firm investment activity and, in particular, can highlight the importance of CLP-driven firm investment on achieving long-run firm success. At first glance, the means in Table 1 seem to confirm this basic idea. Firms with a CLP have on average higher gross investments per capital than other firms (NOCLP). In addition, this table shows 
that establishments that have planned or negotiated over CLPs have lower investment ratios compared to those that adopted a pact. This phenomenon is also the case for establishments that adopted CLPs in the past.

It can be inferred that investment ratios increase at the beginning of a pact (compared to the pre-pact period), but fall again once the pact expires. The comparison between the medians and the means demonstrates that the distribution of gross investment per capital is positively skewed. The majority of the data are found bunched to the left with a long tail to the right.

The development of the investment per employee with respect to the duration of a CLP is depicted in Figure 1, where a kernel-weighted local polynomial smoothing approach is applied (Fan/Gijbels 1996). The graph clearly shows that investments are slightly falling in the first phase of the CLP. Then, after approximately four years, we observe an increase in firm investment. The investment activities peak after roughly eight years, and then a sharp decline occurs. On average, the length of a company-level pact is 2.8 years with a standard deviation of 3.9 years. The frequency distribution of the length of a CLP in our sample is:

\begin{tabular}{l|ccccccc} 
Number of years & 0 & 1 & 2 & 3 & 4 & 5 & $>5$ \\
\hline Number of firms & 306 & 624 & 419 & 248 & 131 & 82 & 234
\end{tabular}

and that of the years of adopting a CLP is:

\begin{tabular}{l|cccccc} 
Years of adopting a & $<=1990$ & $1991-$ & $2000-$ & $2003-$ & $2005-$ & $2007-$ \\
CLP & & 1999 & 2002 & 2004 & 2006 & 2008 \\
\hline Number of firms & 24 & 131 & 149 & 426 & 964 & 350
\end{tabular}

In 2006, in our sample, the average number of employees in firms without a CLP is 124 and that of firms with a CLP is 794. In other words, large firms have a higher propensity to agree to a CLP. Approximately $8 \%$ of all firms have firm level contracts, and approximately $7 \%$ of all firms have a CLP. Among the latter, $60 \%$ are involved in industry collective bargaining, $22 \%$ have firm level collective contracts, and $28 \%$ have agreed opening clauses, which are a necessary condition in firms with industry-wide collective bargaining for adoption of a CLP. 


\section{Econometric results}

\subsection{Investment effects before and during the recession}

Notably, we are mainly interested in the impact of CLPs. Table 2 presents the regression coefficients estimated for different investment equations. We can see that the CLPs have predominately positive but insignificant effects on firm investment. If location investments are explicitly agreed upon in CLPs, the effect on total investments is significantly positive, which is not presented in the tables. In this case, the CLP coefficient is 0.2268 for the period from 2001 to 2009 and 0.1733 for the period from 2001 to 2008. Among the three investment variables (total investment, reinvestment and net investment), the negative coefficients refer to net investment only. The latter coefficients are negative without any exception and are significant more often.

The separate presentation of Panels A and B in Table 2 is intended to show whether the Great Recession has an important influence on the relationship between CLPs and investment. The real gross domestic product (GDP) began contracting in the third quarter of 2008 in the United States and by early 2009 was falling at an annualised pace not observed since the 1950s. In Germany, negative growth rates of GDP were observed from the fourth quarter of 2008 to the fourth quarter of 2009 compared with the previous year's value. In principle, Panels A and B in Table 2 demonstrate a related pattern, albeit estimates broken down by several years reveal some sharp differences - see Table 3. The positive effect of CLPs on total investment is evidently lower if the major recession year of 2009 is incorporated. The same phenomenon is true if we consider only reinvestment.

Furthermore, an IV estimator is applied, and the results can be found on the right hand side of Table 2. The idea is that the adoption of a CLP is induced by investments, that the association between the introduction of a CLP and an investment decision is likely interdependent. A lower initial level of investment by a firm increases the probability that a CLP will be introduced. An IV instead of an OLS estimator is used to avoid a possible simultaneous bias. As an instrument, we employ an opening clause dummy $(O C=1$, if an opening clause exists; $O C=0$ otherwise). An opening clause means that a firm could deviate from the agreements of an industry-level contract, if some triggering event occurred. For example, such an event might be a bad economic situation. We should note that a CLP is 
often adopted if an opening clause has already existed over a long period of time. However, we do not expect a direct effect on investment due to the existence of an opening clause. Furthermore, a dummy, whether a company agreement exists, and the number of employees are used as additional instruments. The company agreement dummy is employed because firms in such a regime do not need an opening clause to agree to a CLP, but these firms have a higher propensity to adopt a CLP than other firms. It is easier to install a CLP because it is clear who the negotiating partners are. Otherwise, the employees fear that the employer will dominate the negotiation. The number of employees (NoE) is incorporated as we expect that large firms are more interested than small firms in CLPs - see section 4. Clearly, the number of employees has a direct impact on the investment volume. However, a direct effect on the growth rate of the capital stock is at least not obvious.

The LIML instead of the 2SLS estimator is preferred, as we use three instruments. Donald and Newey (2001) have shown that for large numbers of instruments, the LIML should dominate the 2SLS in terms of MSE. Problematically, nearly all instruments may actually be weak instruments or exclusion restrictions may not be fulfilled. We find that the opening clause dummy, the company agreement dummy and the number of employees are statistically significant determinants of CLP using probit estimates. Table A2 in the Appendix demonstrates that F-tests for joint significance of the instruments, excluded from the structural model, and Stock-Yogo tests reject the null hypothesis that the instruments are weak. The F statistic is larger than the rule of thumb value of 10 that is sometimes suggested. The minimum eigenvalue statistic is larger than the critical value of Stock-Yogo tests for the LIML estimator (6.46). A direct test that the instruments do not correlate with the error term is impossible. However, the incorporation of the IV variables and interactions between them in the main equation, i.e. in the investment function, does not show any statistically direct influence on investment. Additionally, in an overidentified model we can test for the validity of the overidentifying restrictions (OIR) following Sargan (1958). In such a test, the residuals from a 2SLS regression are regressed on all included exogenous regressors and on all instruments. Under the null hypothesis a LM statistic of the $\mathrm{N}$ times $\mathrm{R}^{2}$ form has a large-sample $\mathrm{CHI}^{2}(r)$ distribution, where $r$ is the number of overidentifying restrictions. If the OIR test indicates that the null hypothesis should be rejected, this is clear evidence that the model is misspecified. We cast doubt on the suitability of the instrument set. This is not a test of the hypothesis that "the instruments are valid". Nevertheless, the OIR test can be considered as a first hurdle that needs to be overcome in the context of IV estimation. Whenever the OIR test implies rejection of the null hypothesis, this usually means at least one of the instruments would have a significant effect in the structural 
equation. Table A2 shows that the $\mathrm{CHI}^{2}$ statistic is weakly significant $\left(\mathrm{CHI}^{2}=7.72\right)$ for the period 2001-2009 and insignificant for the period 2001-2008 $\left(\mathrm{CHI}^{2}=2.82\right)$.

Therefore, our instruments are acceptable.

The comparison of the OLS and IV estimates in Table 2 shows some similarities and some differences:

- The CLP effect on total and replacement investment is insignificant. This result is consistent with previous estimates regarding the influence of unions and works councils on investment. It seems that CLPs have no effect on replacement and total investment. However, CLPs might stop a firm from facing a negative trend in replacement investment.

- The effect on net investment is negative, and this sign is independent of whether the year of the Great Recession is considered. The existence of a CLP does not prevent the negative effect on firm net investment. Firms that are facing a critical economic situation do not solve their problems by expansion, but by cost reduction and modernisation. When firms are uncertain about whether a consolidation of employee and employer interests via CLP will be successful, firms prefer a strategy of caution with the hope of a long-term recovery.

- The IV estimates compared with the OLS estimates reveal a stronger tendency to result in negative net investment effects and to positive reinvestment effects. In other words, the absolute coefficients of the instrumented estimates are higher than those of the non-instrumented estimates. This result is consistent with other studies (e.g. Card 2001, Machin et al. 2012, Schultz 2002).

- The comparison of Panels A and B in Table 2 highlights that the Great Recession reduces the positive effects of a CLP on reinvestment, while the changes to the negative effects of a CLP on net investment are ambiguous. The success of a CLP is less likely to occur during a crisis.

If we split CLPs between those that are adopted due to a current crisis and those that are installed to improve competitiveness, the latter group demonstrates negative effects and the former demonstrates positive effects for the IV estimates, when the Great Recession year is taken into account (these results are not presented in the tables). A possible explanation for this outcome could be the following: the measures taken by firms that adopted CLPs in response to a current crisis are more radical than those of firms that adopted CLPs in pursuit of improving firm competitiveness. In the former case, a firm's economic problems are more evident, which results in employees who are ready to make stronger concessions in CLP 
negotiations. Therefore, success could be more likely. We have no information to test this presumption.

An examination of the complete estimates in Table A1, column OLS and IV shows negative short-run (a lagged growth rate of capital stock) and long-run effects (the log of the capitalsales ratio). When the recession year 2009 is excluded, we find the same tendency towards negative short-run and long-run effects. Low investment rates in the past and past underinvestment compared to equilibrium investment based on sales lead to more investment. The coefficients of central bargaining (CB), works councils (WOCO) and profit sharing (PS) have the expected signs, but the coefficient values indicate that the influence of these factors is insignificant.

In Tables 3 and 4, the outcome of some robustness checks is presented. The considered period is varied, alternative estimation methods are conducted, and the specification is modified. In Table 3, we run the regressions for the period from 2001 to 2007 and separately for the years from 2006 to 2009. The OLS estimates in line 1 for the period from 2001 to 2007 are nearly the same as those for the period from 2001 to 2008 - cf. Panel B in Table 2. This result supports the hypothesis that in 2008 , the recession had not yet affected the relationship between CLPs and firm investment. This outcome is confirmed by the estimates, which are restricted to analysis of 2008. In contrast, the 2009 estimates highlight a negative investment effect by CLPs.

In line 1 of Table 4, we have estimated a more parsimonious version than the standard model. The three control variables, central bargaining (CB), works councils (WOCO) and profit sharing (PS), are suppressed because the influence is insignificant in Table A1. The CLP coefficient does not change substantially in relation to the coefficient of the standard model, and thus the influence remains insignificant.

A further modification is presented in line 2 of Table 4. Equation (10) is simplified by

$$
\delta_{0 i t}=\delta_{00}+\delta_{01} C L P_{i t}
$$

Here, the original Mairesse approach is only extended by a CLP dummy. Positive CLP effects with weak significance are revealed. Another simplification is the estimation in line 3 , Table 4. ADL $(1,1)$ instead of $\operatorname{ADL}(2,2)$ is assumed; however, we do not prefer this approach. F-tests that compare the sum of squared residuals in line "total investment" and in the 
column OLS of Panel $A$ in Table 2 with that in line 3) show that the $A D L(2,2)$ is superior $(\mathrm{F}=1248$; prob.value $=0.000)$.

In line 4 of Table 4, the standard model is enhanced by time dummies; thus, we use

$$
\delta_{0 i t}{ }^{*}=\delta_{0 i t}+\theta^{\prime} z_{i}
$$

instead of (10), where $z_{i}$ is a vector of time dummies and $\theta$ denotes the vector of the time effects. Again, we have only displayed the CLP coefficients. They show larger investment effects than in the standard model. The effects are also stronger if the recession period 2009 is not accounted for. From year to year, the CLP effect strongly varies - cf. Table 3. In 2009, the year of the Great Recession, CLPs even have a tendency to produce negative effects on total investment.

As some companies do not invest in real capital, we also conducted Tobit estimates. The results can be found on the right hand side of Table 3 and line 5 of Table 4 . The pattern is similar to that of the OLS estimates. We should note that this phenomenon is especially true for pre-recession periods (2006, 2007, 2001-2007) and that the CLP coefficients are systematically lower. If the recession periods are included (2008, 2009, 2001-2008 and 2001-2009), the OLS estimates and the Tobit estimates evidently differ. The Tobit estimation already identifies 2008 as a recession year, which diminishes the effect of a CLP on investment.

From the viewpoint of significance, it makes sense to substitute the endogenous variable, the capital growth rate (I/C), by investment per employee (IpE) or by investment per sales (IpS). For these specifications, we find significantly positive effects of CLP on the regressands IpE and IpS - cf. line 6 and 7, Table 4. An advantage of these estimates is that we do need the capital stock variable that is only indirectly determined and that is thus amenable to measurement errors. Two drawbacks of this procedure, however, should be mentioned. First, the specification is not derived from a theoretical model. Second, we cannot isolate the effects on investment, on the one hand, and the effects on the number of employees and sales, on the other hand.

Furthermore, we check whether time-invariant unobserved heterogeneity influences our results. The random effects estimates (REM), not presented in the tables, do not provide any evidence of such an influence. The coefficients of the CLP dummy are very similar to those of line 1 of Table 2 in Panels A and B. This approach is rejected because the hypothesis of 
independence between regressors and time-invariant firm-specific effects does not hold by the Hausman test $\left(\mathrm{CHI}^{2}=345.28\right.$; prob.value=0.000). However, in addition, the fixed effects estimation is not adequate because the CLP influence would be eliminated. Therefore, we prefer the Hausman-Taylor estimator. The results are presented in line 8 of Table 4, and the complete estimation can be found in column HT of Table A1 in the Appendix. Consistent with the other results, the CLP effect on total investment is positive but insignificant even if we account for the recession year 2009. The effects are lower than the OLS and IV estimates in Table 2.

Additionally, we have incorporated a proxy of cash flow and a proxy of financial limitation, namely a dummy for whether the net profit in the last year was positive and a dummy for whether the establishment had difficulties in acquiring loan capital from private credit institutions. In the former case, the effect on the investment rate is weakly significant, and in the latter it is negatively insignificant. However, the CLP effect remains almost unchanged. Therefore, we have excluded these two variables from further analysis following the principle of a parsimonious specification. The results are not shown in the tables.

\subsection{Phases of company-level pacts}

Our previous results show that firms with a CLP have higher investment rates than other firms. Some possible reasons for this result were discussed in earlier sections. Additionally, we investigate the different investment activities between establishments with and without CLPS

- existing before a CLP is adopted

- induced during the negotiation phase

- caused by a CLP becoming effective

- emerging during the contract period of the CLP

- continuing once the CLP has expired.

It is necessary to investigate the effectiveness of CLPs during the different phases.

Otherwise, an assessment of investment activity can have negative consequences.

Negotiating partners become impatient with investment efforts or the timing of investments may be unsuccessful. 
First, difference-in-differences estimates are presented in line 9 of Table 4. We can see that the differences in investment rates between establishments with and without CLPs are larger if the CLPs are effective in 2008 and 2009, respectively. This result supports the notion that differences before the CLP were adopted are lower than after the adoption. However, we should be cautious about generalising this interpretation. If we separate competitiveness CLPs from crisis CLPS, which are not presented in the tables, we can see that the coefficient $b_{3}$ of the DiD estimator in equation (11) is only positive for the former if the recession year 2009 is excluded. Establishments with competitive pacts were more strongly affected by the Great Recession compared to establishments with crisis pacts. This result confirms earlier estimates and is thus not unexpected. The recession has affected particularly prosperous firms that were strong international competitors.

Second, to test whether the positive investment effect of CLPs is directly due to the adoption of a CLP by a firm or whether investment activities are induced during the contract period of a CLP, the left hand side of Table 5 is presented, where the dummy CLP is substituted by another dummy. This is adopted CLP (aCLP), such that $\mathrm{aCLP}_{\mathrm{it}}=1$, if the CLP is started in firm $\mathrm{i}$ and year $\mathrm{t}$, otherwise $\mathrm{aCLP}_{\mathrm{it}}=0$. The adoption induces strong reinvestments. This result exceeds, on average, the investment level by firms with a CLP during the CLP contract period and by firms without CLPs at all. During the contract duration, the elevated investment activity declines as we can see in the comparisons of the analogous estimates in Table 2, although these estimates are not completely comparable. The effect on the net investment rate of a firm is also positive as the result of an adoption of a CLP, in contrast to that of all CLP firms - cf. Table 2, line net investment. We should mention that the investment effect of the adoption of a CLP is not strongly affected by the recession - compare line $\Delta$ total investment in Panels A and B of Table 5.

Overall, CLPs induce positive initial effects on firm investment, but they do not lead to permanent changes in this regard. This impression is strengthened if we look to the right hand side panel of Table 5. In this case, investment changes in firms with an expired CLP are low compared to those in all other CLP firms. Total investment and reinvestment effects are negative - see coefficients -0.3960 and -0.4429 , respectively, in Panel A and -0.2329 and -0.3682 , respectively, in Panel $B$ of Table 5. The negative effect on reinvestment may be due to the fact that capital stock was renewed during the CLP period and therefore in the following years when the firms had less need for reinvestment. The capital widening in the post CLP period denoted by line $\Delta$ net investment on the right hand side of Table 5 demonstrates positive spillover effects. 
Third, we compare the investment activities of group CLP=1 with those of other groups. This approach allows us to differentiate between the investment effects of further phases. We have information on whether

- $\quad$ an agreement existed in the past and is now discontinued (PCLP);

- $\quad$ negotiations are currently under way for a CLP (NCLP);

- $\quad$ the effort to achieve a CLP has failed in the past (FCLP).

The outcome of the comparisons can be found in Table 6, where firms with different CLP phases are matched with firms that did not have a CLP because either a CLP is in negotiation or CLP negotiations failed. In lines $1 A$ ), 1B), 2A) and 2B), we can see that investment is not higher during the negotiation of a CLP agreement compared with firms with an adopted CLP and with firms with no CLP (NOCLP). Furthermore, investment in firms that are currently negotiating a CLP agreement (NCLP) is lower than in firms with pacts in the past (PCLP) or than in firms in which efforts to achieve an agreement failed in the past (FCLP). This outcome is not only the case for total investment but also for reinvestment and for net investment. These results are not presented in the tables.

We should note that establishments that had pacts in the past or that have attempted to negotiate pacts invest less than establishments without any pacts during the studied period, including the recession phase of 2009 - see lines 3A) and 4A). Although these effects are insignificant, this finding is evidence that investment behaviour is not completely stabilised by CLPS. If CLPs have expired and the firms are affected by a crisis, CLPs reduce firm investment activities. In the pre-recession period - cf. line 3B) - investment in establishments with pacts in the past is higher than investment by establishments without any pacts.

Generally, we can infer from a comparison of Panel A with Panel B in Table 6 that recession mitigates the positive investment effects of CLPs or extends the negative effects. All of these facts support the hypothesis that the adherence to CLPs varies with cyclical conditions. Especially during an economic slump, the compliance of a firm with CLP investment promises seems to be lower than during normal or prosperous cyclical phase.

\subsection{The importance of specific agreements}

CLPs for safeguarding employment security and competitiveness are heterogeneous. There exists a wide bundle of different measures and concessions, which can be made by 
employees and employers. Therefore, we want to investigate, which agreements are successful and which are counterproductive in relation to firm investment. Table 7 represents some results. It is not unexpected that investment rates increase if CLPs have explicitly agreed upon the locations of investments - cf. line 1. Nevertheless, it is remarkable that this effect is stronger during the recession than before. The effect is also positive but insignificant if a suspension of a bargained wage increases or if an arrangement for working time credits is adopted or expanded, respectively-cf. lines 2 and 3. Reorganisation of a firm and requirements for heightened qualifications of the personnel of a firm help to strengthen positive investment effects - cf. line 8. Not all measures of CLPs induce more investments. General employment guarantees, preservation of locations and longer working hours coupled with an adjustment of wages are counterproductive in this sense - cf. lines 4 through 6. Furthermore, a combination of all three measures - cf. line 9 - is not associated with a positive investment climate.

Important factors for firm investment include not only the specific concessions of employees and the promises of an employer but also the agreed contract duration of a CLP. Former investigations on CLPs (Hübler 2005, 2006) have emphasised that CLPs are only successful for positive employment effects in the long-run. This phenomenon could also be relevant in evaluating the effects of CLPs on investment. Line 7 in Table 7 shows that the longer a CLP continues, on average, the higher the investment rate. Note, however, that line 10 shows that a negative effect on firm investment arises when a CLP has a very short or a very long contract period. A permanent abandonment of privileges by employees and a permanent maintenance of additional measures by employers are not effective and are not helpful for a positive investment climate.

\section{Conclusion}

Our estimates show positive coefficients of company-level pacts on total and replacement investment. If locational investments are explicitly agreed in CLPs the effects are significant. Otherwise, the effects are often statistically insignificant. This result is consistent with that of other empirical studies that analyse the correlation between the existence of works councils and investment. The positive coefficients are a hint that CLPs induce (replacement) investments in the majority of establishments under normal economic conditions. Strong variations in the investment behaviour between the firms, imprecise standard errors may be responsible for the insignificance. The implied modernisation of establishments' capital stock 
is driven by reinvestment and not by net investment. The latter is declining under CLP and this result is statistically significant. Generally, firms respond to critical economic situations by investing less, which is especially true with regard to the Great Recession. The contrast between the effects on replacement and net investments under company-level pacts demonstrates that the CLPs are no successful instrument of firms' enlargement but only for a consolidation and modernization of the capital stock.

Furthermore, our findings are mixed with respect to the levels of firm investment during different states of a CLP. First, we cannot detect any positive increase in investment during the negotiation phase. Second, firm investment behaviour is ambiguous for the duration of a finalised CLP. We find that, after the expiration of a CLP, lower reinvestment and a small increase in net investment take place. Total investment during the phase following CLP expiration is less than during the contract phase, but except during economic slumps remains larger than investment by firms that never had CLPS.

We also find empirical evidence that the duration of a CLP is decisive in determining whether investments are induced by a CLP. Long, but not excessively long contracts work best in promoting strong firm investment activities. The results are strongly affected by the Great Recession with an increase in diminishing or disappearing investments. In addition, firm compliance with the very long agreements appears to be lower.

Further research requires data from longer periods where more and better information on financial limitations on investment, financial limitations on cash flows and expectations is available. Empirical investigations should extend to other countries, should analyse simultaneously the effects on employment and investment and should focus more on the influence of specific measures and the specific mixture of measures in relation to the cyclical development of firm investment. CLPs can help to improve the competiveness of an establishment. Nevertheless, permanent CLPs are usually not promising. Employees are not willing to accept concessions over a long period without balanced returns. In fact, they react to unbalanced returns to employee concessions by working at a lower level of labour productivity or by quitting when other firms offer better working conditions. 


\section{References}

Addison, J., Bryson, A., Teixeira, P., Pahnke, A. and L. Bellmann (2010): The State of Collective Bargaining and Worker Representation in Germany: The Erosion Continues. IZA Discussion Paper No. 5030.

Addison J., Teixeira, P., Evers, K. and L. Bellmann (2012): Is the Erosion Thesis Overblown? Evidence from Orientation of Uncovered Employers. IZA Discussion Paper No. 6658.

Addison, J., Schank, Th., Schnabel, C. and J. Wagner (2007): Do Works Councils Inhibit Investment? Industrial and Labor Relations Review 60, 187-203.

Addison; J., Schnabel, C. and J. Wagner (1996): German Works Councils, Profits, and Innovation, Kyklos 49, 555-582.

Addison, J., Schnabel, C. and J. Wagner (2001): Works Councils in Germany: Their Effects on Firm Performance, Oxford Economic Papers 53, 659-694.

Akerlof, G.A. (1982): Labor Contracts as Partial Gift Exchange, Quarterly Journal of Economics 97, 543-569.

Asano, H. (2008): Estimating Capital Investment with Financial Constraints: Comparison of Tobin's $q$ and Real Options Approaches, ASSA Conference New Orleans.

Askildsen, J.E., Jirjahn, U. and S.C. Smith (2006): Works Councils and Environmental Investment: Theory and Evidence from German Panel Data, Journal of Economic Behavior and Organization 60, 346-372.

Baum, C. F., Caglayan, M. and O. Talavera (2010): On the investment sensitivity of debt under uncertainty, Economics Letters 106, 25-27.

Bell, L.A. (1995): The Union Wage Concessions in the 1980s: The Importance of FirmSpecific Factors, Industrial and Labor Relations Review 48, 258-275. 
Bellmann, L., Gerlach, K. and W. Meyer (2008): Company-Level Pacts for Employment, Journal of Economics and Statistics 228,533-553.

Bellmann, L. and H.-D. Gerner (2012a): Continuous Training and Company-Level Pacts for Employment in Germany, Journal of Economics and Statistics 232, 98-115.

Bellmann, L. and H.-D. Gerner (2012b): Company-Level Pacts for Employment in the global crisis 2008/09: First evidence from representative German establishment panel data, International Journal of Human Resource Management 23, 3375-3396.

Bogedan, C., Brehmer, W. and H. Seifert (2011): Wie krisenfest sind betriebliche Bündnisse zur Beschäftigungssicherung? WSI Mitteilungen , 51-59.

Bond, S., Harhoff, D. and J. van Reenen (2005): Investment, R\&D and Financial Constraints in Britain and Germany, Annales d'Économie et de Statistique 79/80, 433-460.

Bronars, S. G. and D. R. Deere (1993): Unionization, Incomplete Contracting, and Capital Investment, Journal of Business 66, 117-132.

Caggese, A. (2007): Testing Financing Constraints on Firm Investment using Variable Capital, Discussion Paper Pompeu Fabra University.

Cappelli, P. (1985): Plant-Level Concession Bargaining, Industrial Relations Review 39, 90104.

Card, D. (2001): Estimating the return to schooling: Progress on some persistent econometric problems, Econometrica 69, 1127-1160.

Card, D., Devicienti, F. and A. Maida (2011): Rent-Sharing, Hold-up, and Wages: Evidence from Matched Panel Data, IZA DP No. 6086.

Donald, S.G. and W.K. Newey (2001): Choosing the number of instruments, Econometrica 69, 1161-1191.

Eaton, J. and A. Verma (2006): Does „Fighting Back“" Make a Difference? The Case of the Canadian Auto Workers Union, Journal of Labor Research 27, 187-212. 
Eisner, R. (1978): Factors in Business Investment, Cambridge (Mass.).

Ellguth, P. and S. Kohaut (2008): Ein Bund fürs Überleben? Betriebliche Vereinbarungen zur Beschäftigungs- und Standortsicherung, Industrielle Beziehungen 15, 209-232.

Ellguth, P. and S. Kohaut (2012): Tarifbindung und betriebliche Interessenvertretung. Aktuelle Ergebnisse aus dem IAB-Betriebspanel 2011. WSI-Mitteilungen 65(4), 297-305.

Fan, J. and I. Gijbels (1996): Local Polynomial Modelling and Its Applications. London: Chapman \& Hall.

Fazzari, S. M., Hubbert, R. G. and B. C. Petersen (1988): Financing Constraints and Corporate Investment, Brookings Papers on Economic Activity, 1, 141-95.

Fischer, G.; Janik, F.; Müller, D. and A. Schmucker (2009): The IAB Establishment Panel things users should know, Schmollers Jahrbuch. Zeitschrift für Wirtschafts- und Sozialwissenschaften 129, 133-148.

Freeman, R. B. and E. P. Lazear (1995): An Economic Analysis of Works Councils. In: J. Rogers and W. Streeck (eds.): Works Councils: Consultation, Representation and Cooperation in Industrial Relations: Chicago, IL: University of Chicago Press, 27-52.

Fuss, C. and P. Vermeulen (2004): Firms' Investment Decisions in Response to Demand and Price Uncertainty, European Central Bank, Working Paper No. 347.

Gürtzgen, N. (2010): Rent-Sharing and Collective Wage Contracts - Evidence from German Establishment-Level Data, Applied Economics 42, 2835- 2854.

Hassel, A. (1999): The Erosion of the German System of Industrial Relations, British Journal of Industrial Relations 37 (3), 483-505.

Hassel, A and B. Rehder (2001): Institutional Change in the German Wage Bargaining System - The Role of Big Companies. MPIfG Working Paper 01/9.

Hübler, O. (2003): Zum Einfluss des Betriebsrates in mittelgroßen Unternehmen auf Investitionen, Löhne, Produktivität und Renten - Empirische Befunde, in: N. Goldschmidt 
(Hrsg.), WunderWirtschaftsWelt.- The New Economy und ihre Herausforderungen, Nomos Verlagsgesellschaft, Baden-Baden, 77-94.

Hübler, O. (2005): Sind betriebliche Bündnisse für Arbeit erfolgreich?, Journal of Economics and Statistics 225/6, 630-652.

Hübler, O. (2006): Zum Einfluss betrieblicher Bündnisse auf die wirtschaftliche Lage der Unternehmen, Review of Economics 57, 121-146.

Jirjahn, U. (1998): Effizienzwirkungen von Erfolgsbeteiligung und Partizipation, Campus, Frankfurt-New York.

Kruse, D. L. (1993): Profit Sharing. Does It Make A Difference? W.E.Upjohn Institute for Employment Research, Kalamazoo, Michigan.

Lesch, H. (2008): Betriebliche Bündnisse für Arbeit in der Metall- und Elektro-Industrie, IW Trends 4/2008.

Machin, S., Marie, O. and S. Vujić (2012): Youth Crime and Education Expansion, German Economic Review 13, 366-384.

Mairesse, J., Hall, B.H. and B. Mulkay (1999): Firm-level investment in France and the United States: An exploration of what we have learned in twenty years, Annales d'Economie et de Statistique 55/56, 27-67.

Massa-Wirth, H. and H. Seifert (2005): German pacts for employment and competitiveness. Concessionary bargaining as a reaction to globalisation and European integration?, Transfer 1/05, 26-44.

Meyer, B. D. (1995): Natural and Quasi-experiments in Economics, Journal of Business and Economic Statistics 13, 151-161.

Mueller, S. (2008): Capital stock approximation using firm level panel data, Journal of Economics and Statistics 228, 357-371.

Mulkay, B., Hall, B.H. and J. Mairesse (2000): Firm Level Investment and R\&D in France and the United States: A Comparison, NBER Working Paper No. W8038. 
Schultz, T. P. (2002): Wage gains associated with height as a form of health human capital, American Economic Review 92, Paper and Proceedings, 349-353.

Seifert, H. and H. Massa-Wirth (2005): Pacts for employment and competitiveness, Industrial Relations Journal 36, 217-240.

Sisson, K. (2001): Pacts for employment and competitiveness - an opportunity to reflect on the role and practice of collective bargaining, Transfer: European Review of Labour and Research 7, 600-615.

Sisson, K. and A. Martin Artiles (2000): Handling restructuring. A study of collective agreements dealing with employment and competitiveness. Luxembourg: Office for the Official Publications of the European Communities.

Spence, M. and S. Hlatshwayo (2011): The Evolving Structure of the American Economy and the Employment Challenge, Working Paper.

Zagelmeyer, S. (2010): Company-level bargaining in times of crisis: The case of Germany, International Labour Office, Industrial and Employment Department, Working Paper No. 9, Geneva. 
Figure 1: Investment per employee (IpE) with respect to the duration of comany-level pact (CD)

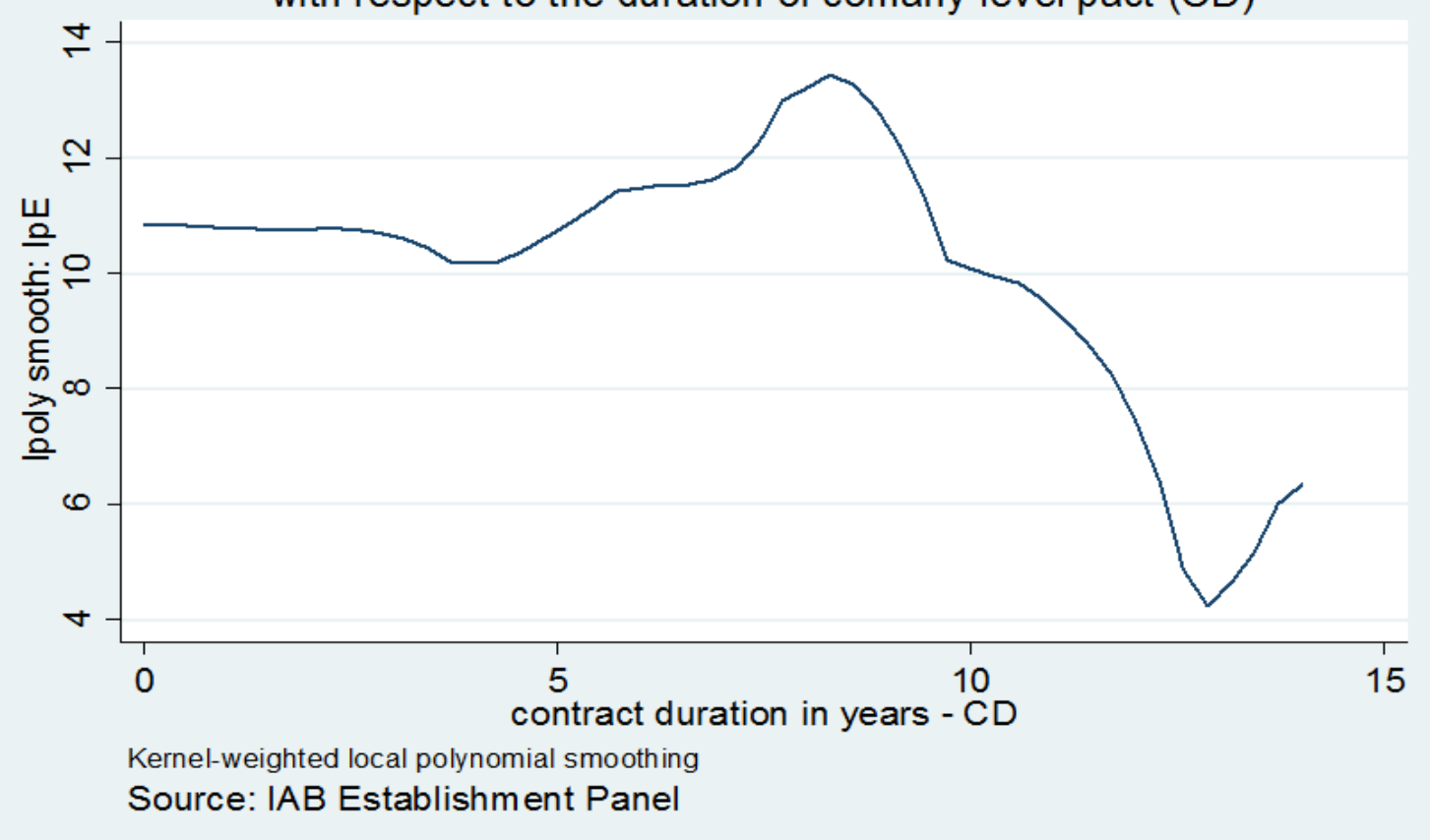


Table 1: Descriptive statistics of gross investment per capital 2006 number of observations, median, mean and standard deviation

\begin{tabular}{lcccr}
\hline Establishment & Observations & Median & Mean & Std. dev \\
\hline $\begin{array}{l}\text { (1) without company-level } \\
\text { pact (NOCLP) }\end{array}$ & 4,594 & 0.1136 & 0.2348 & 0.3069 \\
$\begin{array}{l}\text { (2) with company-level pact } \\
\text { (CLP) }\end{array}$ & 334 & 0.2067 & 0.2922 & 0.2921 \\
$\begin{array}{l}\text { (3) with planned CLP (NCLP) } \\
\text { - negotiations to CLP }\end{array}$ & 41 & 0.2014 & 0.2893 & 0.3058 \\
$\begin{array}{l}\text { (4) with CLP in the past } \\
\text { (PCLP) }\end{array}$ & 79 & 0.1612 & 0.2584 & 0.3067 \\
$\begin{array}{l}\text { (5) with planned but failed CL } \\
\text { (FCLP) }\end{array}$ & 45 & 0.1965 & 0.2849 & 0.3264 \\
\hline
\end{tabular}

Notes: The outliers of investment per capital (IpC) are eliminated, i.e. outside of the 95 percent confidence interval. In other words, firms with $I p C>1.33$ are neglected by assuming that these are measurement errors.

Source: IAB Establishment Panel, 2006 
Table 2: OLS and IV estimates of CLP effects on investment rate - standard model

\begin{tabular}{lcccccc}
\hline & \multicolumn{5}{c}{ OLS } & \multicolumn{2}{c}{ IV } \\
& $N$ & coef & std.err & $N$ & coef & std.err \\
\hline $\begin{array}{l}\text { Panel A: 2001-2009 } \\
\text { total investment }\end{array}$ & 16,599 & 0.0424 & 0.0614 & 16,470 & 0.1341 & 0.3618 \\
reinvestment & 16,349 & 0.0625 & 0.0629 & 16,222 & 0.1192 & 0.2878 \\
net investment & 16,354 & $-0.0202^{\star \star}$ & 0.0083 & 16,222 & $-0.1316^{\star \star \star}$ & 0.0445 \\
& & & & & & \\
\hline & & & & & & \\
Panel B: 2001-2008 & 12,546 & 0.0996 & 0.0810 & 12,564 & 0.2298 & 0.4807 \\
total investment & 12,360 & 0.1179 & 0.0829 & 12,379 & 0.1381 & 0.2234 \\
reinvestment & 12,363 & -0.0156 & 0.0099 & 12,379 & $-0.1356^{\star \star *}$ & 0.0168 \\
net investment & & & & & & \\
\hline
\end{tabular}

Notes: * significant at the $10 \%$ level; ${ }^{\star \star}$ significant at the $5 \%$ level; ${ }^{* \star}$ significant at the $1 \%$ level. For complete estimates of CLP effects on total investment of the standard model in Panel A, see Appendix Table A1. Cluster robust standard errors with respect to the firms. In the IV estimates CLP is instrumented by a dummy "opening clause $=1$, if yes; $=0$ otherwise", by a dummy "company agreement $=1$, if yes; $=0$ otherwise" and by the total numbers of employees.

Source: IAB Establishment Panel, 2001-2010. 
Table 3: Estimates of the standard model for alternative periods

\begin{tabular}{llllll}
\hline Period & $\mathrm{N}$ & $\begin{array}{l}\text { OLS } \\
\text { coef. }\end{array}$ & std.err & $\begin{array}{l}\text { Tobit } \\
\text { coef. }\end{array}$ & std.err \\
\hline $2001-2007$ & 8,784 & 0.0946 & 0.1079 & 0.0849 & 0.1166 \\
2006 & 3,016 & 0.2799 & 0.2669 & 0.2041 & 0.2752 \\
2007 & 3,344 & 0.0421 & 0.0693 & 0.0403 & 0.1028 \\
2008 & 3,765 & $0.1094^{*}$ & 0.0586 & 0.0012 & 0.0994 \\
2009 & 3,929 & -0.1085 & 0.0765 & $-0.1895^{\star}$ & 0.1134
\end{tabular}

Notes: * significant at the $10 \%$ level; ${ }^{* \star}$ significant at the $5 \%$ level; *** significant at the $1 \%$ level. The coefficient of the CLP dummy variable on total investment and cluster robust standard errors with respect to the firms are presented. The same control variables are incorporated as in Appendix Table A1.

Source: IAB Establishment Panel, 2001-2010. 
Table 4: Robustness checks of the standard model

\begin{tabular}{|c|c|c|c|c|c|c|}
\hline & \multicolumn{3}{|c|}{ Panel A: 2001-2009 } & \multicolumn{3}{|c|}{ Panel B: 2001-2008 } \\
\hline & $\mathrm{N}$ & coef & std.err & $\mathrm{N}$ & coef & std.err \\
\hline $\begin{array}{l}\text { 1) parsimonious } \\
\text { specification }^{a}\end{array}$ & 19,466 & 0.0552 & 0.0541 & 15,492 & 0.0855 & 0.0575 \\
\hline 2) Mairesse approach b) & 19,469 & $0.1445^{*}$ & 0.0810 & 15,485 & 0.1956 & 0.1017 \\
\hline 3) $\operatorname{ADL}(1,1)^{\mathrm{c})}$ & 19.501 & 0.0190 & 0.0568 & 15,422 & 0.0575 & 0.0609 \\
\hline $\begin{array}{l}\text { 4) extended } \\
\text { specification }^{\mathrm{d})}\end{array}$ & 19,417 & 0.0856 & 0.0854 & 15,439 & 0.1433 & 0.1072 \\
\hline 5) Tobit estimates & 16,599 & -0.0110 & 0.0719 & 12,546 & 0.0635 & 0.0911 \\
\hline 6) $I p E^{e)}$ & 15,994 & $0.0036^{\star *}$ & 0.0016 & 12,174 & $0.0037^{\star \star}$ & 0.0018 \\
\hline 7) $\left(\mathrm{IpS}^{f)}\right.$ & 15,994 & $0.0856^{\star *}$ & 0.0431 & 12,174 & $0.0678^{\star}$ & 0.0353 \\
\hline 8) Hausman-Taylorg) & 15,994 & 0.0008 & 0.0114 & 12,174 & 0.0123 & 0.0153 \\
\hline 9) $\left.\mathrm{DiD}^{\mathrm{h}}\right)$ & 35,722 & 0.0797 & 0.1487 & 30,057 & 0.2707 & 0.2730 \\
\hline
\end{tabular}

Notes: * significant at the $10 \%$ level; ** significant at the $5 \%$ level; ${ }^{* \star \star}$ significant at the $1 \%$ level. The coefficient of the CLP dummy variable on total investment and cluster robust standard errors with respect to the firms are presented. The same control variables as in Appendix Table A1 are incorporated in lines 5 through 8.

a) without central bargaining, works council and profit sharing dummy as control variables

b) regressors: lagged growth rate of capital stock, growth in sales, lagged growth in sales, log of the capital-output ratio, log of sales and CLP dummy.

c) autoregressive distributed lag model: $\operatorname{ADL}(1,1)$ instead of $A D L(2,2)$ as in the other specifications.

d) with time dummies as additional control variables

e) dependent variable: investment per employee.

f) dependent variable: investment per sales.

g) complete Hausman-Taylor (HT) estimates of Panel A - cf. Appendix Table A1.

h) the estimated coefficient is $b_{3}$ of the DiD model in equation (11). In Panel $A$ the differences between period 2001-2008 and 2009 are compared, in Panel B analogously those of period 2001-2007 and 2008.

Source: IAB Establishment Panel, 2001-2010. 
Table 5: The investment effects of adoption and expiring of CLPS

\begin{tabular}{lcccccc}
\hline & \multicolumn{3}{c}{ Adopted CLP } & \multicolumn{3}{c}{ Expired CLP } \\
& $N$ & coef & std.err & $N$ & coef & std.err \\
\hline Panel A: 2001-2009 & & & & & & \\
$\Delta$ total investment & 21,160 & $0.1910^{\star \star}$ & 0.0834 & 1,027 & -0.3960 & 0.3641 \\
$\Delta$ reinvestment & 20,568 & $0.2235^{\star \star \star}$ & 0.0803 & 989 & -0.4429 & 0.3465 \\
$\Delta$ net investment & 20,579 & 0.0014 & 0.0238 & 989 & 0.0474 & 0.2929 \\
Panel B: 2001-2008 & & & & & & \\
$\Delta$ total investment & 16,505 & $0.1943^{*}$ & 0.1188 & 784 & -0.2329 & 0.4610 \\
$\Delta$ reinvestment & 16,035 & $0.1970^{*}$ & 0.1197 & 755 & -0.3682 & 0.4025 \\
$\Delta$ net investment & 16,044 & 0.0285 & 0.0259 & 755 & 0.0893 & 0.1603
\end{tabular}

Notes: * significant at the 10\% level; ** significant at the 5\% level; *** significant at the $1 \%$ level. Cluster robust standard errors with respect to the firms are presented. The control variables are change of firm size, bargaining, works council, profit sharing, time and industry dummies. In the left hand side panel, firms who have adopted a CLP in period $t$ are compared with all other firms. In the right hand side panel, firms whose pact is expired in period $t$ are only compared with firms in which a pact still exists.

Source: IAB Establishment Panel, 2001-2010. 
Table 6: The investment effects of CLPs under alternative treatment and control groups

\begin{tabular}{lllll}
\hline Treatment group & Control group & $\mathrm{N}$ & coef & std.err \\
\hline Panel A: 2001-2009 & & & & \\
1A) CLP & NCLP & 1,108 & $0.1154^{* *}$ & 0.0603 \\
2A) NCLP & NOCLP & 15,463 & $-0.1098^{\star}$ & 0.0639 \\
3A) PCLP & NOCLP & 15,457 & -0.0095 & 0.0624 \\
4A) FCLP & NOCLP & 15,508 & -0.0956 & 0.0776 \\
Panel B: $2001-2008$ & & & & \\
1B) CLP & NCLP & 798 & $0.1301^{*}$ & 0.0743 \\
2B) NCLP & NOCLP & 11,749 & -0.0853 & 0.0679 \\
3B) PCLP & NOCLP & 11,739 & 0.0065 & 0.0737 \\
4B) FCLP & NOCLP & 11,780 & -0.0598 & 0.0860 \\
\hline
\end{tabular}

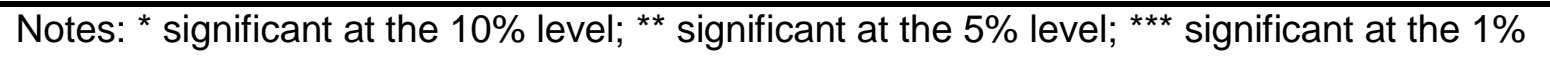
level. Cluster robust standard errors with respect to the firms. Control variables are the same as in Table A1.

CLP: $\quad$ with company-level pact.

NCLP: planned company-level pact, on-going negotiations.

NOCLP: no company-level pact.

PCLP: company-level pact in the past, expired.

FCLP: planned company-level pact, but negotiations failed.

Source: IAB Establishment Panel, 2001-2010. 
Table 7: The investment effects of specific measures of CLPS

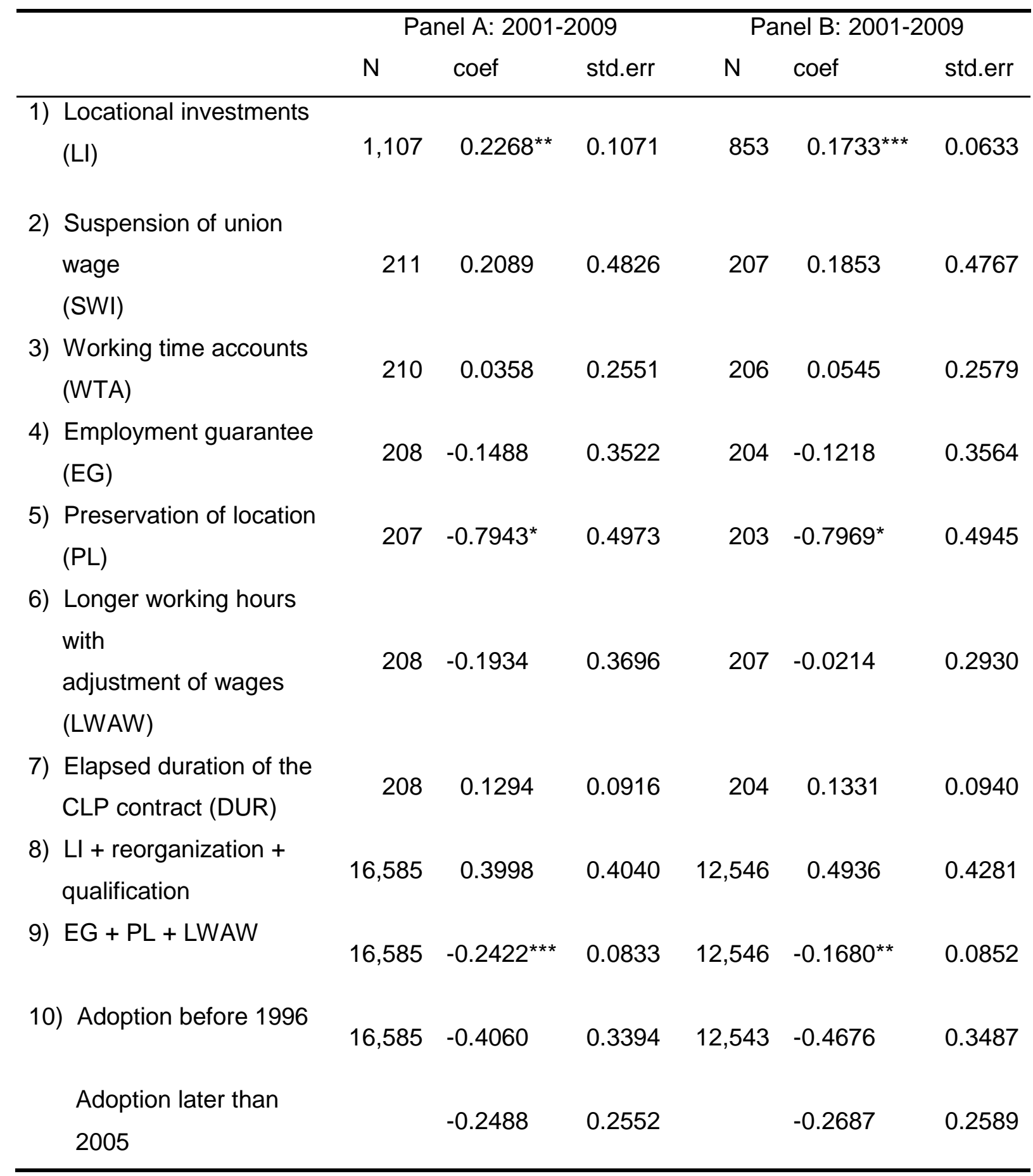

Notes: * significant at the $10 \%$ level; ** significant at the $5 \%$ level; ${ }^{* \star \star}$ significant at the $1 \%$ level. The coefficient of the CLP dummy variable and the cluster robust standard errors with respect to the firms are presented. The same control variables are incorporated as in Appendix Table A1. In lines 1 through 7, the dummy is only defined for those firms who have answered ( $D=1$ if the measure is agreed; $D=0$ if the measure is not agreed), while in lines 8 through 10 the dummy variable of the measure $D$ (e.g. LI or EG) includes all observations $(D=1$ if the measure is agreed; $D=0$ otherwise). A sum, e.g. $E G+P L+L W A W$, means that all mentioned measures were arranged.

Source: IAB Establishment Panel, 2001-2010. 


\section{Appendix:}

Table A1: Effects of CLPs on total investment (the growth rate of capital stock) standard model 2001-2009

\begin{tabular}{|c|c|c|c|c|c|c|}
\hline & & OLS & IV & & $\mathrm{HT}$ & \\
\hline Variables & coef & std.err & coef & std.err & coef & std.err \\
\hline $\begin{array}{l}\text { Company-level } \\
\text { pact (CLP) }\end{array}$ & 0.0424 & 0.0614 & 0.1341 & 0.3618 & 0.0008 & 0.0114 \\
\hline $\begin{array}{l}\text { Number of } \\
\text { employees/1,000 }\end{array}$ & $0.1150^{*}$ & 0.0686 & & & $0.0215^{\star \star \star}$ & 0.0071 \\
\hline Lagged GRC & $-0.0117^{\star \star \star}$ & 0.0041 & $-0.0123^{\star \star *}$ & 0.0041 & -0.0007 & 0.0006 \\
\hline Growth in sales & 0.0682 & 0.0471 & $0.0633^{\star \star}$ & 0.0361 & $0.0225^{\star \star \star}$ & 0.0046 \\
\hline $\begin{array}{l}\text { Lagged growth in } \\
\text { sales }\end{array}$ & -0.0557 & 0.0401 & -0.0590 & 0.0374 & 0.0059 & 0.0067 \\
\hline $\begin{array}{l}\text { Log of the capital- } \\
\text { sales ratio }\end{array}$ & $-0.2880^{\star \star \star}$ & 0.0267 & $-0.2209 * \star *$ & 0.0106 & $-0.0862^{\star \star \star}$ & 0.0033 \\
\hline Log of sales & $-0.0455^{\star \star \star}$ & 0.0124 & $-0.0320^{\star * \star}$ & 0.0117 & -0.0420 *** & 0.0066 \\
\hline Construction & $-0.2061^{\star \star \star}$ & 0.0549 & $-0.1706^{\star \star *}$ & 0.0475 & 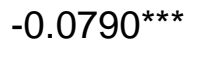 & 0.0230 \\
\hline Trade & 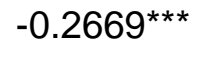 & 0.0678 & $-0.1570 * \star \star$ & 0.0437 & $-0.1628^{\star \star \star}$ & 0.0202 \\
\hline Traffic & 0.0973 & 0.0827 & 0.0537 & 0.0725 & 0.0294 & 0.0339 \\
\hline $\begin{array}{l}\text { Telecommunicatio } \\
\mathrm{n}\end{array}$ & 0.0532 & 0.0796 & 0.0420 & 0.6080 & 0.0402 & 0.3027 \\
\hline Company services & $-0.1690^{\star \star \star}$ & 0.0470 & $-0.1205^{\star \star \star}$ & 0.0431 & $-0.0798^{\star \star \star}$ & 0.0224 \\
\hline Other services & -0.0696 & 0.0522 & -0.0109 & 0.0470 & $-0.0738^{\star \star \star}$ & 0.0240 \\
\hline Central bargaining & -0.0194 & 0.0366 & -0.0015 & 0.0327 & 0.0110 & 0.0071 \\
\hline Works council & 0.0307 & 0.0531 & 0.0005 & 0.0632 & $0.0519 * \star \star$ & 0.0178 \\
\hline Profit sharing & -0.0332 & 0.0425 & -0.0163 & 0.0395 & $-0.1387^{\star \star \star}$ & 0.0285 \\
\hline Const & $0.4188^{\star \star}$ & 0.1974 & 0.3110 & 0.1824 & $0.8717^{\star \star \star}$ & 0.1440 \\
\hline $\begin{array}{l}\text { Number of } \\
\text { observations }\end{array}$ & 16,599 & & 16,470 & & 15,994 & \\
\hline $\mathrm{R}^{2}$ & 0.0363 & & 0.0282 & & & \\
\hline $\mathrm{CHI}^{2}$ & & & & & $997.27^{\star \star \star}$ & \\
\hline
\end{tabular}

Notes: * significant at the $10 \%$ level; ** significant at the $5 \%$ level; *** significant at the $1 \%$ level. Cluster robust standard errors with respect to the firms. GRC is the growth rate of the capital stock. In the IV estimates CLP is instrumented by a dummy "opening clause $(O C)=1$, if yes; $=0$ otherwise", by a dummy "company agreement $(C A)=1$, if yes; $=0$ otherwise" and by the total numbers of employees (NoE). HT means Hausman-Taylor panel estimator.

Source: IAB Establishment Panel, 2001-2010 
Table A2: Tests on weak instruments, exclusion restrictions and overidentifying restrictions of the standard model

Panel A: 2001-2009 Panel B: 2001-2009

\begin{tabular}{|c|c|c|}
\hline \multicolumn{3}{|l|}{ Testing on weak instrument: } \\
\hline F-test statistic: & $211.29 * \star \star$ & $179.19 * * \star$ \\
\hline \multicolumn{3}{|l|}{ Testing on exclusion restriction: } \\
\hline \multicolumn{3}{|l|}{ t-test statistics: } \\
\hline Opening clause (OC) & -1.27 & -0.83 \\
\hline Company agreement (CA) & 0.95 & 0.74 \\
\hline Number of employees (NoE) & 0.77 & 0.81 \\
\hline $\mathrm{OC} * \mathrm{CA}$ & -1.01 & 1.01 \\
\hline OC*NoE & 0.41 & -1.23 \\
\hline $\mathrm{CA}^{*} \mathrm{NoE}$ & -1.02 & -1.72 \\
\hline \multicolumn{3}{|c|}{ Testing on overidentifying restrictions (OIR): } \\
\hline $\mathrm{CHI}^{2}$-test statistic: & $7.72^{\star}$ & 2.82 \\
\hline
\end{tabular}

Source: IAB Establishment Panel, 2001-2010 